\title{
IMANÊNCIA E AMOR NA FILOSOFIA DE ESPINOSA*
}

José Ezcurdia**

Resumo: O texto apresenta uma interpretação pouco comum da filosofia de Espinosa, pois recupera não só os elementos propriamente modernos sobre que ela se constitui, mas também a peculiar apropriação que o filósofo realiza de conceitos ligados à tradição neoplatônico-cristã como vida, amor Dei intellectualis, caridade ou a própria figura de Cristo consignados em sua correspondência. Neste sentido, a explicitação do conteúdo e da relação entre os conceitos de imanência e de amor surge como ponto de apoio para sublinhar que a doutrina de Espinosa articula-se ao levar a cabo uma renovação de algumas das mais arcaicas posições religiosas judaico-cristãs - a concepção do amor ao outro como divinização do homem em Deus e como realização de Deus no homem, fundamentalmente -, que satisfazem as diretrizes de uma Modernidade que na afirmação da autonomia do sujeito encontra um dos pilares que asseguram sua emergência.

Palavras-chave: vida, caridade, Cristo, imanência, amor.

É, por sob a massa de conceitos aparentados ao cartesianismo e ao aristotelismo, a intuição que foi a de Espinosa, intuição que nenhuma fórmula, por mais simples que seja, será suficientemente simples para exprimir. Digamos, para nos contentar com uma aproximação, que é o sentimento de uma coincidência entre o ato pelo qual nosso espírito conhece perfeitamente a verdade e a operação pela qual Deus a engendra, idéia de que a "conversão" dos alexandrinos, quando se torna completa, é a mesma coisa que a "processão", e que quando o homem, que saiu da divindade, chega a reentrar nela, somente percebe um movimento único onde havia visto primeiramente dois movimentos inversos de ir e de retornar - a experiência moral encarregando-se aqui de resolver uma contradição lógica e de fazer, através de uma brusca supressão do Tempo, com que voltar seja um ir.

(Bergson 1, p. 1351)

O pensamento de Espinosa, por sua profundidade, riqueza e dinamismo, ha

* Tradução de Homero Santiago.

** Professor da Universidade de Guanajuato (México). 
séculos tem sido fonte das mais diversas interpretações e dos mais acalorados debates. Vários dos autores maiores da tradição filosófica, explícita ou tacitamente, beberam da filosofia de Espinosa no momento de construir suas próprias doutrinas. Basta recordar os casos emblemáticos de Leibniz, Hegel e Nietzsche, que viram na doutrina desse filósofo um espaço interessante de reflexão. Inumeráveis ao longo dos séculos foram os autores, investigadores e estudiosos da filosofia que se aproximaram da doutrina espinosana para realizar uma interpretação de conjunto ou assinalar um ou outro aspecto dela. No pensamento contemporâneo, a obra de Gilles Deleuze, Espinosa e o problema da expressão (Deleuze 5), ocupa um lugar capital. Deleuze, nesta obra, analisa a transformação das noções de emanação e participação na noção de imanência, tão cara ao sistema espinosano. Neste espaço não seria apropriado tentar realizar um inventário dos investigadores que dedicaram seus esforços a analisar e explicar o pensamento de Espinosa. Textos como $A$ anomalia selvagem de Antonio Negri (Negri 17), que sublinha o caráter fundamentalmente revolucionário e libertador do pensamento desse autor; ou A estratégia do conatus de Laurent Bove (Bove 2), que realiza uma fina análise do papel da memória, da imaginação e do amor como mecanismos de afirmação e resistência ético-política do sujeito, são, entre muitas outras, obras sugestivas que nas últimas décadas contribuíram para tecer a rica rede de estudos sobre Espinosa. Ultimamente textos como "Hábito, conhecimento e virtude em Espinosa”, de Syliane Malinowsky-Charles (Malinowsky-Charles 16), que mostra o vínculo e o sentido dessas noções no sistema espinosano, ou O suicídio: desejo impossivel ou o paradoxo da morte voluntária em Bento de Espinosa de Diana Cohen (Cohen 4), que faz do estudo do tema do suicídio uma via de acesso ao pensamento e à deliberação ética em Espinosa, dão mostras do amplo horizonte de reflexões que nosso filósofo suscita. Como dizíamos, pela profundidade, riqueza e dinamismo que caracterizam a filosofia de Espinosa, é difícil sequer resumir sumariamente a variedade de autores com enfoques divergentes que lhe dedicam sua atenção: hegelianos e nietzschianos, racionalistas e intuicionistas, materialistas e espiritualistas, místicos e ateus, entre outras escolas filosóficas, historicamente disputaram-se tanto a herança intelectual como o mais categórico repúdio à doutrina de nosso autor. O pensamento de Espinosa, atrevemo-nos a sugerir, poderia caracterizar-se como uma máquina produtora de sentido, pelo que é natural que se torne terra fértil para o afazer e as polêmicas dos filósofos.
No texto que ora apresentamos, abordamos duas noções fundamentais no sistema espinosano - tempo e amor - que, a nosso ver, podem constituir-se como chaves interpretativas para assinalar a forma e o lugar que ele ocupa no elenco da tradição filosófica: Espinosa, justamente mediante a noção de imanência, ao mesmo tempo em que desarma a estrutura da filosofia aristotélico-tomista relança a posição religioso judaicocristão mais arcaica do amor como caridade, no qual o amor ao outro, a própria caridade, é tanto plenificação do homem em Deus como realização de Deus no homem. De nossa perspectiva, Espinosa faz da noção de imanência não o princípio de uma ruptura radical com a tradição filosófica neoplatônico-cristã, mas o fundamento da determinação da autonomia de um homem moderno que, na construção de uma sociedade amorosa e justa, alcança a exata afirmação de sua forma. Tradição judaico-cristã e Modernidade encontram uma mútua promoção na doutrina de Espinosa, ao passo que o vínculo do homem com Deus — vínculo baseado no amor a Deus como amor ao homem — traduz-se na afirmação da autonomia do próprio homem, a qual se faz capital na determinação do próprio mundo moderno. As noções de imanência e amor constituem eixos fundamentais na doutrina de Espinosa, na medida em que permitem resolver as tensões que se estabelecem entre os elementos judaico-cristãos e propriamente modernos que aparecem em sua doutrina. Repassemos estas posições mais de perto.

$$
* * *
$$

É patente aos estudiosos da História da Filosofia que Espinosa é um autor moderno que desmonta o andaime conceitual da filosofia aristotélico-tomista, na medida em que estabelece uma noção de imanência em que Deus ou a substância identifica-se com a Natureza. Para Espinosa, Deus se determina como uma causa que se constitui ao manifestar-se em infinitos atributos infinitos e perfeitos (entre os quais se encontram o pensamento e a extensão) que exprimem a essência absolutamente infinita dele. Estes atributos, por sua vez, são o âmbito de atualização de uma série de leis da natureza ou modos infinitos que se afirmam como tais ao exprimir-se num domínio de ilimitados modos finitos. Substância e atributos (Natureza Naturante, Natura naturans) e modos infinitos ou leis naturais (Natureza Naturada, Natura naturata) apresentam uma relação 
de causalidade imanente, isto é, uma relação causal em que a causa manifesta-se no efeito e, ao manifestar-se nele, constitui-se como tal.

Espinosa nos diz na Ética:

Deus é causa imanente de todas as coisas, e não causa transitiva. Tudo o que existe, existe em Deus e deve ser concebido por Deus; pelo que Deus é causa das coisas que nele existem [...] Em seguida, fora de Deus não pode dar-se nenhuma substância, isto é, uma coisa que, fora de Deus, exista em Deus [...] Por conseguinte, Deus é causa imanente de todas as coisas, e não causa transitiva. (Espinosa 7, E, I, prop. XVIII e dem.) $)^{1}$

Todas as coisas são em Deus, na medida em que Deus mesmo se realiza nelas. A Natureza Naturante determina-se como tal enquanto se exprime e se constitui na Natureza Naturada. Na doutrina desse filósofo, o Uno, a substância e seus atributos, afirma-se na medida em que se manifesta ou se exprime no múltiplo, entendido como uma série de leis ou modos infinitos, que se realizam na ordem de uma multiplicidade ilimitada:

Da necessidade da Natureza divina devem seguir-se infinitas coisas em infinitos modos, isto é, tudo o que pode cair sob um intelecto infinito.

Esta proposição deve ser evidente a quem quer, se pelo menos atentar nisto: da definição dada de uma coisa qualquer, o intelecto conclui várias propriedades, que efetivamente seguem-se necessariamente dela (isto é, da própria essência da coisa), e conclui tanto mais quanto a definição da coisa exprime mais realidade, isto é, que a essência da coisa definida envolva mais realidade. Como, porém, a natureza divina possui absolutamente infinitos atributos, cada um dos quais exprime uma essência infinita no seu gênero, é de conseqüência que da sua necessidade devam seguir-se infinitas coisas em infinitos modos, isto é, tudo o que pode cair sob um intelecto infinito. (Espinosa 7, E, I, prop. XVI e dem.)

A substância divina possui infinitos atributos infinitos que exprimem ou explicam a absoluta perfeição e a essência dela, a partir da produção de uma multiplicidade ilimitada de modos em cada atributo infinito, que se vê determinada como tal graças à ordem das leis naturais. Neste sentido, a própria passagem da unidade à multiplicidade — a explicatio da tradição neoplatônica — é um momento fundamental da ontologia espinosana, dado que a substância se determina como causa imanente, isto é, como causa que atua, justamente ao exprimir-se e realizar-se em seus efeitos. ${ }^{2}$

Para Espinosa, Deus, ao constituir-se no objeto de sua expressão, a própria Natureza, solapa os fundamentos de toda metafísica em que Deus apresenta um caráter transcendente relativamente a sua criação. Deus na metafísica de Espinosa não é diferente de sua manifestação, na medida em que ele se constitui como causa imanente dela: as noções de transcendência, eminência, participação ou criação, próprias da metafísica aristotélico-tomista, caem ante uma concepção do real em que Deus ou a substância identifica-se com a natureza entendida como um ilimitado domínio de modos sujeitos a leis. A noção de causa final e a hierarquia dos seres características da filosofia escolástica — Deus, os anjos, o homem, as substâncias animal e vegetal, o acidente, por exemplo vêem-se substituídas por uma ontologia do pleno em que primam os motivos da igualdade e da univocidade, e em que a noção moderna de lei natural regula as relações entre os objetos ou modos finitos.

Segundo nosso autor, a substância, ao manifestar-se na Natureza, constitui-se como ordem imanente, enquanto as leis naturais que determinam a ordem da multiplicidade surgem como o âmbito de sua atualização. Para nosso autor, a noção moderna de lei natural surge como o coração de Deus ou da natureza, substituindo as categorias metafísicas de forma e matéria, substância e acidente, próprias da lógica de gêneros e espécies.

Espinosa aponta no Tratado teológico-político:

Por governo de Deus, entendo a ordem fixa e imutável da natureza, ou seja, a concatenação das coisas naturais. Já dissemos, e demonstramos algures, que as leis universais da natureza, segundo as quais todas as coisas são feitas e determinadas, não são outra coisa senão os eternos decretos de Deus, os quais implicam sempre eterna verdade e necessidade. Dizer, portanto, que tudo acontece segundo as leis da natureza é o mesmo que dizer que tudo é 
ordenado por decreto e por orientação de Deus. (Espinosa 12, TTP, III, 45-46)

O Deus de Espinosa surge como uma série de leis naturais, que se realizam enquanto ordem necessária de toda multiplicidade. Deus, ao constituir-se em sua manifestação, na Natureza Naturada, determina-se como os modos infinitos ou leis naturais em que esta se constitui. ${ }^{3}$

Ora, é precisamente no momento da explicação do Uno no múltiplo que a substância de Espinosa adquire uma de suas significações fundamentais não só como lei natural e ordem imanente, mas também como força e potência de existir, já que é só na medida em que a substância se manifesta e exprime no domínio da Natureza Naturada que se determina precisamente como substância.

Ao passo que a Natureza Naturante se realiza ao exprimir-se na Natureza Naturada, a causação imanente e infinita desta última, a força que lhe dá fundamento, surge como princípio de sua determinação:

Tenho para mim que mostrei assaz claramente que da suma potência de Deus, ou seja, da sua natureza infinita, fluem necessariamente, ou se seguem com a mesma necessidade, infinitas coisas em infinitos modos, isto é, tudo: da mesma maneira que da natureza do triângulo se segue desde toda a eternidade que os seus três ângulos são iguais a dois retos. Pelo que a onipotência de Deus esteve em ato desde toda a eternidade e permanecerá para a eternidade igualmente na mesma atividade. Destarte, a onipotência de Deus é estabelecida de uma maneira muito mais perfeita, pelo menos a meu parecer. (Espinosa 7, E, I, prop. XVII, esc.).

A manifestação e realização da Natureza Naturante na Natureza Naturada supõe a determinação da substância como força ou poder de existir, já que o ato mesmo de sua manifestação é o princípio da afirmação de sua forma. Desta maneira, as noções de causalidade imanente e potência de existir vinculam-se e surgem como traços fundamentais do conceito de Deus de nosso autor. ${ }^{4}$

Esta determinação da substância como força ou poder de existir ganha conteúdo graças à noção de vida. A vida é precisamente a capacidade expressiva ou explicativa pela qual a substância dá lugar à manifestação em que se constitui como tal:

A força pela qual Deus persevera em seu ser nada mais é do que sua essência; falam bem aqueles que dizem que Deus é a Vida. (Espinosa 8, CM, VI, 260)

Deus, enquanto poder de existir, é vida que se afirma satisfazendo sua essência como força e atividade. Deus, ao determinar-se como causa imanente, aparece como vida que se constitui em sua própria atividade, na forma da própria multiplicidade que aparece como seu âmbito expressivo.

Como dizíamos, para nosso autor as noções de poder de existir e imanência às quais se articula sua noção de substância não implicam o estabelecimento de uma ontologia da mediação, da participação ou da emanação, em que os diferentes domínios do real estruturar-se-iam numa relação hierárquica ordenada em função de causas finais. Pelo contrário, a noção de lei natural junto de uma concepção da substância como poder de existir implicam uma ontologia do pleno, exprimem a forma de Deus enquanto causa imanente. Os diferentes momentos da ontologia deste autor - substância e atributos (Natureza Naturante) e modos infinitos ou leis naturais e modos finitos (Natureza Naturada) - são apenas regiões e relações no ser que exprimem uma mesma potência e uma mesma realidade. ${ }^{5}$

Até aqui se deu conta da ontologia de Espinosa com base nas noções de poder de existir ou vida e de lei natural. Neste sentido, parece que a noção de imanência seria o princípio para estabelecer a concepção de Deus ou a Natureza como uma força cega que se resolve em sua própria estrutura e em sua própria afirmação. A noção de imanência teria assim por objeto restituir ao real sua forma como uma atividade necessária sujeita a leis que não apresentaria nenhum tipo de hierarquia entre seus elementos constitutivos. A ontologia espinosana seria deste modo o exato reverso da metafísica aristotélicotomista e para dar conta de sua estrutura bastaria apenas opor à noção de transcendência 
e seus conceitos subsidiários - hierarquia, participação, causa final, por exemplo a de imanência e as noções de poder de existir e lei natural: a negação de um Deus transcendente bastaria para rastrear a orientação da moderna ontologia espinosana, na medida em que essa negação permite estreitar a emergência da própria concepção de Deus ou a Natureza como poder de existir e lei natural.

Neste ponto cabe assinalar que estas afirmações são imprecisas. A ontologia de Espinosa estabelece uma concepção de Deus ou substância que se articula não só pelas mencionadas noções de poder de existir e lei natural, mas também por aquela de um amor em que se atualiza um autoconhecimento e uma autocriação em que Deus ou a substância determina-se como tal: para Espinosa, Deus ou a substância articula-se não só como um poder de existir, mas também como um amor que faz deste um poder de pensar. Espinosa introduz em sua concepção imanentista do real um elemento proveniente das tradições judaico-cristã e neoplatônica, que coexiste com os elementos propriamente modernos estabelecidos em sua doutrina: a substância aparece não unicamente como uma força cega e ordem natural, mas adquire também uma consciência que se faz possível tanto pela autogeração como pela apropriação que, em seu intelecto infinito ou nas leis do atributo do pensamento, tem de si mesma. A substância espinosana conhece-se a si mesma em sua expressão, a Natureza, que no intelecto infinito de Deus devolve-lhe sua imagem, atualizando sua forma justamente como amor. Vejamos isso mais de perto.

Espinosa assinala que a manifestação da substância em seus diferentes atributos estabelece uma incomunicabilidade entre eles, já que cada um exprime uma essência infinita, que se concebe como uma substância em seu gênero.

Dado que cada atributo implica uma essência, que é uma infinita forma de perfeição em si mesma, nenhum atributo com seus modos pode ser determinado nem concebido por outro:

Com efeito, cada atributo é concebido por si, sem nenhum outro. Pelo que os modos de cada atributo implicam o conceito do seu atributo, mas não o de outro; e assim têm Deus por causa apenas enquanto ele é considerado sob esse atributo de que eles são modos, e não enquanto é considerado sob qualquer outro. (Espinosa 7, E, II, prop. VI, dem.)
A incomunicabilidade dos atributos aparece como uma doutrina do espinosismo, derivada de uma concepção da substância como o absolutamente infinito, que se exprime em infinitos atributos infinitos, que se concebem como substâncias em seu gênero e, justamente por isso, não podem estabelecer relação alguma.

Aqui cabe assinalar que esta doutrina da incomunicabilidade dos atributos encontra-se acompanhada da teoria da correspondência na ordem causal dos mesmos. A ordem causal que exprime a atividade ou potência de existir divina nos diferentes atributos permite estabelecer uma correspondência na articulação dos modos de cada um. Assim, por exemplo, a cadeia causal e a lei nas quais se ordena a multiplicidade do atributo pensante correspondem à ordem e à lei que prevalecem nos modos do atributo extenso, justamente por ter um mesmo princípio e ordem imanente, a própria substância:

A ordem e a conexão das idéias é a mesma que a ordem e a conexão das coisas. (Espinosa 7, E, II, prop. VII)

Esse par de teses, ou seja, a doutrina da incomunicabilidade dos atributos (derivada da noção da substância como o absolutamente infinito) e a da correspondência da ordem causal deles (que tem sua base na teoria da substância como causa e ordem imanente), encontra a determinação de seu lugar na ontologia de Espinosa ao constituírem aspectos derivados da concepção de uma substância una. Esta concepção faz da existência dos atributos, e da ordem imanente comum a todos eles, não estruturas contraditórias, mas momentos interiores entre si da manifestação em que a substância se constitui como tal. Desta maneira, a ordem prevalecente no atributo pensante divino é uma só e a mesma que a ordem do atributo extenso, só que compreendida sob a perspectiva da essência que lhe compete:

É necessário que aqui, antes de prosseguirmos, recordemos o que acima demonstramos: que tudo o que pode ser concluído por um intelecto infinito como constituindo a essência da substância [os infinitos atributos] pertence a uma única substância, e, por conseqüência, a substância pensante e a substância extensa são uma e a mesma substância, compreendida ora sob um atributo, ora sob outro. (Espinosa 7, E, II, prop. VII, dem.) 
Para Espinosa o real não é como uma série de parcelas - os diferentes atributos - que careceria de um fundamento comum. A extensão, o pensamento e o restante dos atributos são regiões de uma unidade una que, ao determinar-se como ente perfeito que possui toda forma de realidade, isto é, como o absolutamente infinito, exprime-se neles e constitui-se a si mesma.

Ora, dado que todos os atributos incomunicáveis apresentam uma mesma raiz e ordem imanente, encontram seu comum denominador precisamente no intelecto infinito de Deus, quer dizer, nas leis da natureza que regem os modos do atributo pensante. O intelecto infinito de Deus possui a idéia ou forma, não só de todos os modos do atributo pensamento, mas também a de todos os modos de todos os atributos, na medida em que guarda uma correspondência com eles, fundada numa mesma ordem imanente e, em última instância, na participação imediata de todos os atributos num princípio uno. Assim, este princípio uno e imanente, o intelecto infinito de Deus, é síntese ou complicatio de todos os infinitos atributos e seus modos, e determina-se, por isso, como um infinito poder de pensar:

Vês, portanto, como e por que considero o corpo humano como uma parte da natureza. E também considero a alma humana como uma parte da natureza. Estabeleço, com efeito, que há na natureza uma potência infinita de pensar que, enquanto infinita, contém em si objetivamente toda a natureza e cujos pensamentos se encadeiam do mesmo modo que a natureza, seu objeto pensado (ideatum). (Espinosa 6, Ep. XXXII, 173)

O intelecto infinito de Deus aparece como princípio imanente e síntese da forma em que se articulam os modos dos ilimitados atributos que exprimem a forma divina. $\mathrm{O}$ intelecto infinito de Deus é causa e nervo no qual Deus manifesta e recupera sua natureza. Tal intelecto exprime, por isso, a infinita potência de pensar de Deus.

Nesse ponto cabe sublinhar que o intelecto infinito, enquanto lei e idéia de todos os modos finitos e infinitos de todos os atributos, realiza-se na Natureza Naturada. Assim como a potência de existir de Deus satisfaz-se na produção de ilimitados modos sujeitos a leis, sua infinita potência de pensar encontra cumprimento exatamente no modo infinito do pensamento, síntese da ordem que rege os modos dos infinitos atributos:

Quanto à questão principal, considero ter demonstrado de maneira bastante clara e evidente que o intelecto, embora infinito, pertence à Natureza Naturada, e não à Natureza Naturante. (Espinosa 6, Ep. IX, 45).

A criação imediata da Natureza Naturada consiste no princípio pelo qual Deus se conhece, já que tal Natureza, expressão da substância divina, encontra sua forma no intelecto infinito de Deus, que mostra a Deus sua própria forma: Deus, como num espelho, conhece-se em seu intelecto infinito e nesse conhecimento é que se determina como infinito poder de pensar. Para Espinosa, a causalidade imanente se desdobra não só no plano do absoluto poder de existir como no do absoluto poder de pensar, já que a existência mesma de Deus ou da Natureza Naturada implica uma forma ou idéia em que este exprime-se, recupera-se, conhece-se e determina-se como tal.

Deus se conhece como causa que está totalmente presente em seu efeito, como pensamento que se cria e se conhece a si mesmo, na medida em que seu intelecto infinito complica toda forma dos ilimitados atributos existentes, que exprimem ou explicam sua essência divina:

É o que certos hebreus parecem ter visto como que através de um nevoeiro, os quais afirmam que Deus, o intelecto de Deus e as coisas por ele compreendidas são uma e a mesma coisa. (Espinosa 7, E, II, prop. VII, esc.)

Deus se constitui em sua manifestação, na Natureza Naturada, concebida como um intelecto infinito que complica toda diversidade que exprime e manifesta sua própria forma, satisfazendo sua essência como vida e atividade. Deus se determina como absoluto poder de pensar, na medida em que seu intelecto infinito condensa a forma de infinitos atributos que manifestam sua essência dinâmica.

O conhecimento que Deus tem de si, a idéia em que se realiza, traduz-se também no amor infinito que tem de si mesmo, na medida em que se conhece justamente como sua própria causa. Segundo Espinosa, Deus, ao conhecer-se, conhece-se como causa de si, e 
esse conhecimento traduz-se numa apropriação e numa plenitude que atualizam um amor que aparece como sua forma:

Deus se ama a si mesmo com um amor intelectual infinito. Deus é absolutamente infinito, isto é, a natureza de Deus goza de uma perfeição infinita, e isto acompanhado da idéia de si mesmo, isto é, da idéia da sua causa; e foi isto que nós dissemos que era o amor intelectual, no corolário da proposição 32 desta parte. (Espinosa 7, E, V, prop. XXXV e dem.)

Espinosa, além de conceber Deus como força absoluta de existir, vê também nele uma potência absoluta de pensar. Este poder de pensar, toda vez que se constitui como a síntese dos atributos que exprimem a perfeição divina, constitui, no intelecto infinito de Deus, a idéia em que Deus se conhece como causa de si e se ama a si mesmo.

O fato de que nosso autor não reconheça em Deus uma forma transcendente, que se constitua como causa final e que seja diferente da Natureza, não implica que não veja nele um Deus que se conhece e se ama na medida em que se conhece como causa de si, determinando-se como um Deus que se relaciona consigo mesmo, quer dizer, como um Deus que é pessoa, afirmando-se precisamente não só como poder de existir, mas também como poder de pensar: poder de existir e poder de pensar surgem como aspectos correlativos de uma mesma concepção de Deus imanente ou Natureza Naturada, na medida em que sua existência não se concebe sem uma forma — a idéia que Deus tem de si -, e sua forma não se realiza senão na existência. Existência e pensamento são como momentos de um Deus que é causa de si e determina-se como pessoa justamente ao conhecer-se e amar-se como causa de si mesmo.

Esta afirmação encontra sua expressão numa identificação das causas formal e eficiente na natureza divina.

Deus é potência absoluta, que se constitui como existência, enquanto desdobramento e explicação de infinitos atributos e leis, que manifestam a perfeição divina. Deus é um pensamento que se realiza como tal, enquanto síntese e complicação de toda forma exprime como poder de existir.

Em algumas passagens do Tratado teológico-político, Espinosa identifica o poder de existir de Deus com sua vontade, e o poder de pensar, com sua inteligência:

[...] a natureza da vontade de Deus, a qual não se distingue do intelecto divino a não ser na perspectiva da nossa razão; quer dizer, a vontade de Deus e o seu intelecto de Deus são, na realidade, uma e a mesma coisa, distinguindo-se apenas do ponto de vista das idéias que nós fazemos a respeito do intelecto divino. (Espinosa 12, TTP, IV, 62.)

Na Ética, ele assinala expressamente:

A potência de pensar de Deus é igual à sua potência atual de agir. Isto é, tudo o que se segue formalmente da natureza infinita de Deus segue-se também em Deus objetivamente na mesma ordem e com a mesma conexão da idéia de Deus. (Espinosa 7, E, II, prop. VII, cor.)

A concepção de Deus como potência de existir passa a ser incluída como momento da determinação total de Deus como poder de existir e poder de pensar. A forma divina realiza-se no ato de sua manifestação, pelo que sua manifestação é idêntica a sua própria forma. Intelecto e vontade, causa formal e eficiente, são idênticos na ontologia de Espinosa: o intelecto infinito de Deus é a Natureza Naturante que se constitui na Natureza Naturada, fazendo da idéia de Deus, de Deus que se cria, conhecese e ama-se a si mesmo, a satisfação de Deus mesmo como vida. O Deus de Espinosa, apesar de identificar-se com a Natureza Naturada, não aparece só como força, mas também como amor e consciência. ${ }^{6}$

Como antecipamos, apesar da negação das noções de transcendência, causa final, criação a partir

do nada, Espinosa concebe um Deus que se conhece a si mesmo e se determina como consciência absoluta.

Neste sentido a própria vida, a força e o alento que sustentam o homem e o mundo, é para este filósofo a vida de um Deus-consciência, que não é alheio ao Deus da tradição judaico-cristã?: 
O espirito de Deus significa a própria alma ou a inteligência do homem, como em Jó: "E o espírito de Deus estava em minhas vísceras", por alusão à passagem do Gênesis, ou seja: "que Deus infundiu no homem uma alma viva" Assim, Ezequiel, profetizando aos mortos, diz: "Dar-vos-ei o meu espírito e vivereis, quer dizer, devolver-lhes-ei a vida". (Espinosa 12, TTP, I, 25)

O Deus de Espinosa é um Deus vivo no sentido da tradição judaico-cristã, no qual a própria vida se traduz tanto em fonte de existência como de uma consciência que não é mais que autoconhecimento e amor. O Deus espinosano é um Deus-consciência, na medida em que, uma vez que é causa de si, constitui-se ao conhecer-se e amar-se precisamente enquanto causa de si mesmo.

Neste ponto podemos perguntar: Que significação tem o fato de Espinosa emparelhar em sua concepção ontológica as noções de imanência e amor? Tem sentido vincular uma concepção imanentista do real em que Deus se identifica com a Natureza a outra em que Deus se ama a si mesmo e se determina como pessoa? Acaso a convivência de ambas as perspectivas metafísicas constitui um reflexo de alguns vestígios — a própria concepção de Deus como amor e consciência -, produto da formação religiosa juvenil de nosso autor? As noções cartesianas de pensamento e extensão, as próprias noções de Deus como força e lei natural, não logram acaso estabelecer uma ontologia plenamente moderna na medida em que se desenvolvem sobre o fundo de uma concepção em que a substância surge não só como poder de existir, mas também como poder de pensar? Neste sentido poderíamos afirmar que a ontologia de nosso autor é presa de uma incongruência de fundo? Será que Espinosa estabelece uma concepção moderna da substância como lei natural que arrasta com dificuldade certos elementos da filosofia medieval?

É aqui que a nosso ver as concepções éticas espinosanas podem dar resposta a tais perguntas. Espinosa estabelece uma ética que, por seu corte e sua orientação, ao mesmo tempo em que restitui à posição religiosa um sentido e uma viabilidade que o caráter hierarquizante e estatizante da filosofia aristotélico-tomista terminara por anular, outorga ao sujeito uma autonomia que é fundamental na emergência do mundo moderno.

Espinosa, a partir de sua ontologia imanentista, possibilita uma recuperação da posição originária religiosa judaico-cristã fundamental, já que impulsiona um vínculo do homem com Deus que se satisfaz mediante a realização do reino de Deus na ordem humana e não pela negação da própria ordem humana, no interesse do próprio vínculo do homem com Deus. É a partir dessa perspectiva que, em nosso juízo, é possível compreender por que é que Espinosa emparelha à própria concepção de Deus como amor e consciência a tese imanentista: o homem, ao afirmar Deus em si mesmo, promove não só seu vínculo com Deus como também a determinação de um sujeito em que a marca da autonomia é constitutiva. Modernidade e religiosidade se entrelaçam no pensamento de Espinosa, na medida em que ele, ao restituir à posição religiosa judaico-cristã — justamente com o concurso da noção de imanência - seu sentido fundamental de uma divinização do homem a partir da realização da ordem divina no humano, colhe uma autonomia humana que é capital na emergência do próprio mundo moderno.

Repassemos as noções espinosanas de conhecimento adequado e verdade, assim como as de perseverar no ser, conatus e virtude, para tornar explícitas estas concepções.

Espinosa assinala que o sujeito, enquanto modo finito do atributo pensante, determina-se fundamentalmente por sua capacidade de conhecer. O conhecimento surge como forma do sujeito, ao ser este um modo em que o atributo divino do pensamento se exprime e se constitui como tal.

A essência do homem é constituída por certos modos dos atributos de Deus; a saber, por modos de pensar: a idéia de todos esses modos é anterior por natureza e, sendo ela dada, os outros modos (aqueles a que a idéia é anterior por natureza) devem dar-se no mesmo indivíduo e, portanto, a idéia é o que constitui o ser da alma humana. (Espinosa 7, E, II, prop. XI, dem.)

O sujeito é uma modificação do atributo do pensamento, quer dizer, uma idéia pela qual é possível o conhecimento, em termos de princípio e apreensão de diversas 
representações. A idéia aparece como forma da alma, ao ser o princípio de todas as representações e atos do pensamento como lembranças, volições, etc., a partir das quais o sujeito afirma sua própria capacidade de conhecer. Neste sentido, o próprio sujeito, justamente enquanto modo do atributo pensante, não pode conhecer mais que idéias e representações, dado que cada atributo se concebe como uma substância em seu gênero e, por isso, não mantém comunicação com nenhum outro. Nosso filósofo aponta que o objeto de conhecimento do sujeito são conceitos ou idéias, já que não poderia conhecer os modos de outros atributos, dado que existe uma incomunicação entre eles. Espinosa não vê no intelecto uma prancha de cera, na qual se imprimiriam as formas provenientes da sensibilidade e se articulariam em imagens sensíveis e conceitos universais, mas vê nele uma força pensante, um pensamento vivo e ativo como o atributo do qual é modificação e expressão, capaz de criar seus próprios objetos.

A concepção do atributo como potência e atividade é o princípio para determinar a essência dos modos pensantes como formas capazes de criar os objetos em que dão cumprimento a sua essência justamente como conhecimento:

Por idéia entendo um conceito da alma, que a alma forma por ser uma coisa pensante.

Digo conceito de preferência a percepção porque a palavra percepção parece indicar que a alma padece em virtude do objeto; em troca, conceito parece exprimir uma ação da alma. (Espinosa 7, E, II, def. III e exp.)

O sujeito, ao ser modificação do atributo pensante que exprime a força divina, pode criar os objetos nos quais realiza sua forma como idéia. O sujeito determina-se como idéia que atualiza sua forma na produção de conceitos, que são objeto de seu conhecimento. ${ }^{8}$ Deste modo, numa primeira instância, a posição epistemológica espinosana cai dentro de um enfoque idealista em que o objeto de conhecimento do sujeito são seus próprios conceitos ou representações e ele não precisa mais do que destes para determinar a verdade. Assim, a tradicional definição de verdade como a adequação ou correspondência do intelecto à coisa é deslocada pela coerência entre as idéias e a noção de idéia adequada. Para Espinosa o conceito de adequação assinala a certeza interna e a verdade intrínseca da idéia:
Por idéia adequada entendo a idéia que, enquanto é considerada em si mesma, sem relação com o objeto, tem todas as propriedades ou determinações intrínsecas de uma idéia verdadeira. (Espinosa 7, E, II, def. IV)

O autor vê no sujeito uma potência de pensamento capaz de criar idéias que são objetos de seu conhecimento. Na medida em que essas idéias tenham os traços próprios da idéia adequada serão, verdadeiras e não requererão uma correspondência com uma forma transcendente para determinarem-se como tais.

É aqui que Espinosa utiliza os conceitos cartesianos de clareza e distinção como critério fundamental para determinar a verdade intrínseca ou o caráter adequado das idéias. Toda idéia que seja simples, que se conheça em si mesma e se distinga de todas aquelas com as quais guarda relação, em suma, toda idéia que seja clara e distinta, é objeto de um conhecimento imediato e, por isso, fonte de verdade. Pelo contrário, toda idéia obscura e confusa é princípio do erro, da ficção ou da dúvida:

Portanto, de nenhum modo se deve temer que finjamos algo, desde que percebamos uma coisa clara e distintamente [...] não podendo a idéia fingida ser clara e distinta, mas somente confusa, e como toda confusão procede de que a mente conhece só em parte a coisa íntegra ou composta de muitas, não distinguindo o conhecido do desconhecido, além de que olha conjuntamente e sem nenhuma distinção para os múltiplos elementos contidos em cada coisa. (Espinosa 10, IE, II, 24)

A análise das idéias, sua redução aos elementos simples em que se compõem e a determinação de seu caráter claro e distinto, são o princípio para satisfazer cabalmente a forma ativa do intelecto e produzir idéias adequadas, idéias que possuem a verdade como forma intrínseca. A adequação das idéias tem seu fundamento no método de sua determinação e na força criativa do sujeito, dado que Espinosa estabelece uma incomunicabilidade de atributos, que exclui toda contrastação, seja empírica ou em relação a uma forma transcendente, que ultrapasse a forma do atributo pensante. ${ }^{9}$ 
Ora, apesar de a epistemologia espinosana poder ser abordada a partir de uma concepção do sujeito como modo do atributo pensante que não guarda vínculo algum com nenhum modo de outro atributo, ela também pode ser iluminada a partir da teoria da correspondência dos atributos. Partindo dessa teoria — que se funda na participação imediata dos próprios atributos numa mesma ordem imanente - , toda verdade determinada em função das idéias ou essências objetivas encontra seu paralelo nas coisas físicas ou essências formais. Na medida em que a ordem e a conexão das idéias é a mesma que a ordem e a conexão das coisas, a determinação de uma idéia adequada é idêntica à forma de um modo do atributo extenso:

Entre a idéia verdadeira e a adequada, não reconheço nenhuma outra diferença a não ser esta: o termo verdadeira tem em conta somente a concordância da idéia com seu objeto (pensado) e o termo adequada, em troca, a natureza da idéia em si mesma; de modo que, em realidade, entre a idéia verdadeira e a adequada não há nenhuma diferença, afora essa relação extrínseca. (Espinosa 6, Ep. LX, 270)

Toda idéia adequada ou essência objetiva corresponde a uma essência formal dos modos dos diferentes atributos, dado que existe uma correspondência entre os próprios atributos, fundada em sua comum sujeição às leis da natureza. A adequação espinosana não é o princípio de uma verdade que seria refém de um mero solipsismo, mas sim, pela presença em todo atributo de uma mesma ordem imanente, a própria verdade se abre à determinação das essências formais ou coisas físicas, articuladas nas próprias leis naturais.

Espinosa estabelece uma concepção epistemológica em que o sujeito, ao atualizar seu princípio imanente, produz as idéias adequadas que são objeto de seu conhecimento. A concepção de imanência, destarte, restitui ao sujeito uma autonomia epistemológica que a metafísica aristotélico-tomista terminara por anular: o sujeito, da perspectiva de nosso autor, não tem que dobrar seus conceitos à forma de um suposto princípio transcendente para colher a verdade. Para Espinosa a verdade é assunto humano e só humano, na medida em que é produto da atividade do homem que satisfaz sua forma como conhecimento enquanto modo do atributo pensante do qual é expressão, e no qual tal atributo afirma sua forma.

Estas teses relativas à autonomia epistemológica do sujeito cobram um contexto de inteligibilidade mais amplo quando analisadas a partir das noções de conatus e perseverar no ser. Segundo Espinosa o homem caracteriza-se como uma força que tende a afirmar sua existência através dos modos dos atributos extenso e pensante em que se constitui. Esta força não possui nada em si mesma que limite sua própria forma como poder de existir.

Toda coisa se esforça, quanto está em si, por perseverar no seu ser. As coisas singulares, com efeito, são modos pelos quais os atributos de Deus se exprimem de modo certo e determinado, isto é, coisas que exprimem de modo certo e determinado a potência de Deus, em virtude da qual ele existe e age, e nenhuma coisa tem em si nada por que possa ser destruída, isto é, que suprima a sua existência, mas, ao contrário, ela opõe-se a tudo o que poderia suprimir a sua existência; portanto se esforça, tanto quanto pode e está em seu poder, por perseverar no seu ser. (Espinosa 7, E, III, prop. VI e dem.)

O esforço com que cada coisa persevera em seu ser é idêntico a sua própria essência. Cada modo dos ilimitados atributos determina-se como tal enquanto sua essência caracteriza-se como conatus ou perseverar no ser, justamente como um conatus por afirmar sua forma que de maneira alguma pode negar-se a si mesma. A própria vida do corpo, a qual dá lugar à capacidade de agir e ser afetado, ou a da alma, fundamento da caracterização do sujeito como ser racional capaz de produzir idéias adequadas e verdadeiras, traduz-se num perseverar no ser que constitui a essência do próprio sujeito.

Neste contexto Espinosa assinala que o perseverar no ser que determina a forma do homem articula-se no desejo. O desejo é o princípio pelo qual a essência do sujeito realiza-se, justamente enquanto perseverar no ser. Seja como ser racional, seja como corpo que atua e é afetado, o sujeito afirma-se e constitui-se, ao possuir um desejo que o impele a existir: ${ }^{10}$

Este esforço, quando se refere só à alma, chama-se vontade, mas quando se refere ao mesmo tempo à alma e ao corpo, chama-se 
apetite. $\mathrm{O}$ apetite não é senão a própria essência do homem, de cuja natureza se segue necessariamente o que serve para a sua conservação; e, portanto, o homem está determinado a fazer essas coisas. Além disso, entre o apetite e o desejo não há nenhuma diferença, a não ser que o desejo se refere geralmente aos homens quando têm consciência do seu apetite e, por conseguinte, pode ser assim definido: o desejo é o apetite de que se tem consciência. (Espinosa 7, E, II, prop. IX, esc.)

O sujeito determina-se como uma natureza essencialmente desejante, já que o próprio desejo é o princípio a partir do qual se realiza como conatus. O desejo é a essência do homem, enquanto este torna patente sua natureza como poder de existir em que se satisfaz o caráter ativo da substância que surge como seu princípio imanente.

Neste sentido, o desejo mesmo é o princípio para determinar o que é o bem e o que é o mal, já que sua satisfação, mediante a apreensão e posse de diversos objetos, é o fundamento para dar cumprimento à forma do homem como perseverar no ser. Enquanto os objetos satisfazem cabalmente o desejo do homem, são bons e, enquanto o contrariam, são maus, já que o impedem de promover seu conatus e afirmar sua forma como poder de existir.

Para Espinosa, as coisas não são boas nem más em si mesmas, mas tão-somente na medida em que são objeto do desejo humano:

É, portanto, evidente, em virtude de tudo isso, que não nos esforçamos por fazer uma coisa que não queremos, não apetecemos nem desejamos qualquer coisa porque a consideramos boa; mas, ao contrário, julgamos que uma coisa é boa porque tendemos para ela, porque a queremos, a apetecemos e desejamos. (Espinosa 7, E, III, prop. IX, esc.)

O desejo e a sua satisfação são o princípio para a determinação do valor. Tudo aquilo que favoreça a potência de agir do homem, entendido como conatus que consta de corpo e alma, será bom. Pelo contrário, tudo aquilo que impeça seu perseverar no ser, será mau.
Este autor não vê no valor uma forma transcendente a partir da qual o homem oriente seu desejo e determine o valor das coisas concretas. Segundo ele, as coisas valem porque são desejadas. Assim, o bem e o mal são produtos da capacidade racional do sujeito, que encontra a orientação de seus julgamentos na afirmação de seu corpo e de sua alma e na satisfação de seu próprio desejo. ${ }^{11}$

Ora, nesse contexto Espinosa aponta que o sujeito, ao afirmar seu princípio imanente, dá lugar às afecções ativas que exprimem com exatidão a atualização de sua essência. Quando deixa de fazê-lo, padece aquelas afecções que minam a afirmação da mesma. As afecções alegres e a apreensão de objetos que afirmam a forma do sujeito como conatus são para Espinosa sinônimo de vida, na medida em que consistem na atualização de sua própria forma enquanto poder de existir. As afecções passivas ou tristes, pelo contrário, são resultado de uma disposição passiva do corpo e da imaginação que brindam ao sujeito objetos que são nocivos para sua forma.

Neste sentido, nosso autor assinala que, ao serem a alma e o corpo aspectos do conatus em que se determina o homem como perseverar no ser, as afecções ativas se identificam com as idéias adequadas da razão - idéias que se caracterizam por ter um caráter claro e distinto - já as afecções passivas ou paixões, com as idéias mutiladas e confusas da imaginação:

A nossa alma, quanto a certas coisas, age, mas, quanto a outras coisas, padece, isto é, enquanto tem idéias adequadas, é necessariamente ativa em certas coisas; mas, enquanto tem idéias inadequadas, é necessariamente passiva em certas coisas.

Daí se segue que a alma está sujeita a um número de paixões tanto maior quanto maior é o número de idéias inadequadas que tem; e, ao contrário, é tanto mais ativa quanto mais idéias adequadas tem. (Espinosa 7, E, III, prop. I e cor.)

O sujeito determina-se como perseverar no ser que vê nas idéias adequadas e nas afecções ativas a satisfação de sua essência. O homem, enquanto conatus, faz de seu corpo e de sua mente, das idéias e das afecções em que se constitui, aspectos de uma mesma afirmação a partir da qual dá cumprimento ao desejo que o impele a permanecer na existência. ${ }^{12}$

É aqui que Espinosa utiliza a noção de virtude. A virtude é o incremento do 
conatus do sujeito, graças à afirmação de seu princípio vital e à posse de tudo aquilo que é útil para promover sua permanência no ser:

Por virtude e potência entendo a mesma coisa, quer dizer, a virtude, enquanto se refere ao homem, é a própria essência ou natureza do homem, enquanto tem o poder de fazer algumas coisas que só podem ser compreendidas pelas leis de sua própria natureza. (Espinosa 7, E, IV, def. VII)

Quanto mais cada um se esforça e pode procurar o que lhe é útil, isto é, conservar o seu ser, tanto mais é dotado de virtude; e, ao contrário, quanto mais cada um omite conservar o que é útil, isto é, o seu ser, tanto mais é impotente. (Espinosa 7, E, IV, prop. XX)

A virtude consiste na afirmação da essência do sujeito, que torna atual sua natureza como conatus que consta de alma e corpo. A virtude é a realização da essência do sujeito, enquanto poder de agir e existir, que se afirma na produção de múltiplas afecções alegres e idéias adequadas e na posse de tudo aquilo que é útil para promover sua própria forma. O autor não concebe a virtude como a sujeição do corpo e da conduta do sujeito a uma lei ou valor imposto a partir de sua exterioridade e que se articulasse sob a forma de um Deus transcendente. A virtude não é tampouco o cumprimento de um imperativo categórico ao qual a variabilidade sensível se tenha que dobrar vendo-se negada, nem o resultado de uma ética que tenha como centro o cumprimento do dever pelo dever. A virtude é a afirmação da vida, entendida a própria vida como o incremento do poder de existir do corpo e da alma do sujeito. ${ }^{13}$

Neste contexto cabe assinalar que para nosso autor a virtude se satisfaz com exatidão na construção do que ele denomina o indivíduo superior. É precisamente na construção do indivíduo superior — construção fundada no amor como caridade — que o sujeito, toda vez que tem que encontrar o objeto adequado pelo qual verá precisamente afirmada sua essência — o próprio homem —, vincular-se-á a seu princípio imanente e realizará a forma mesma de Deus na ordem do humano, conseguindo ele próprio sua própria divinização

Para Espinosa o indivíduo superior constitui-se como a soma de uma série de sujeitos que compartilham uma natureza comum. Neste indivíduo superior cada sujeito vê potencializada sua forma, justo ao identificar-se e nutrir do poder de existir de todos aqueles que o compõem.

Com efeito, se, por exemplo, dois indivíduos, absolutamente da mesma natureza, unem-se um ao outro, formam um indivíduo duas vezes mais potente que cada um deles separadamente. Portanto, nada mais útil ao homem que o homem. Os homens, digo, não podem desejar nada mais vantajoso para conservar o seu ser do que estarem todos de tal maneira de acordo em tudo que as almas e os corpos de todos formem como que uma só alma e um só corpo, e que todos, em conjunto, o quanto possam, se esforcem por conservar o seu ser e que todos, em conjunto, procurem o útil comum a todos. (Espinosa 7, E, IV, prop. XVIII, esc.)

O objeto mais útil ao homem é, segundo Espinosa o próprio homem, pois, ao concordar em natureza, permite-lhe construir um indivíduo superior na qual verá promovida e acrescida a afirmação de seu conatus. O indivíduo superior é o objeto que mais convém ao homem, pois nele verá potencializada e afirmada sua natureza, superando a própria limitação característica de sua essência individual. Para Espinosa o homem não é o lobo do homem, muito pelo contrário, para este filósofo, o homem é para o homem um Deus. É no amoroso reconhecimento ao homem que o próprio homem gozará do objeto que melhor afirma sua natureza, na medida em que este se identifica plenamente com ela, permitindo-lhe formar um indivíduo superior, que nutrirá e afirmará seu próprio conatus. As idéias adequadas da razão, as afecções ativas e ditosas, têm no amor ao homem a forma de um conatus que se afirma e cresce, pois encontra a possibilidade de constituir uma unidade de existência mais potente que a sua própria e que passa a ser o âmbito de sua atualização.

Aqui cabe assinalar que a relação imediata entre os sujeitos, que é justamente princípio do indivíduo superior, torna-se possível enquanto aprofundam o que é comum a eles, isto é, sua própria essência. Assim, na medida em que o sujeito afirma sua própria essência como vida e poder de existir, traz à tona aquilo que permite sua correspondência ou comunhão com outros homens: a participação imediata do sujeito em seu próprio 
princípio, o intelecto infinito de Deus, as leis do atributo pensante - que é síntese das leis ou modos infinitos de todo atributo - é o fundamento para fundar uma relação intersubjetiva em que os homens se realizam ao constituir um indivíduo superior.

Espinosa, na Reforma do intelecto, assinala como o cumprimento da essência do homem dá-se na união dela com seu princípio imanente, o intelecto infinito de Deus ou a natureza universal. Este intelecto infinito é o fundamento da união dos homens em uma unidade superior a eles mesmos:

Nada, considerado em sua natureza, será dito perfeito ou imperfeito; principalmente depois que soubermos que tudo o que acontece observa uma ordem eterna e obedece às leis fixas da Natureza. Como, porém, a fraqueza humana não alcança aquela ordem pelo seu conhecimento, e, entretanto, o homem concebe uma natureza humana muito mais firme que a sua atual e, vendo, ao mesmo tempo, que nada obsta a que adquira tal natureza, sente-se incitado a procurar-se os meios que o conduzam a tal perfeição. Tudo o que possa ser meio para chegar a isso chama-se verdadeiro bem; o sumo bem, contudo, é chegar ao ponto de gozar com outros indivíduos, se possível, dessa natureza. Qual, porém, seja ela mostraremos em seu lugar, a saber, o conhecimento da união da mente com toda a natureza. Este é, portanto, o fim ao qual tendo: adquirir uma natureza assim e esforçar-me por que muitos a adquiram comigo; isto é, pertence também à minha felicidade fazer com que muitos outros entendam o mesmo que eu, a fim de que o intelecto deles e seus apetites convenham totalmente com o meu intelecto e o meu apetite. E para que isso aconteça, é preciso entender tanto da Natureza quanto baste para adquirir semelhante natureza [...]. (Espinosa 10, IE, I, 8)

A edificação do indivíduo superior radica na participação imediata do homem em seu princípio imanente, o intelecto infinito de Deus. Esta participação imediata dá lugar ao vínculo dos homens a partir da realização de sua natureza comum, o próprio intelecto divino, no qual os homens verão realizada e potencializada sua essência. Neste contexto, Espinosa aponta que a função da razão e a produção de afecções ativas surgem como a ante-sala para chegar a uma forma de conhecimento não racional em que o sujeito vê a realização de sua essência na vivência imediata de sua forma como existindo em Deus. Nosso autor assinala que o sujeito é capaz de autoconhecer-se e autodeterminar-se através das idéias e emoções em que se exprime sua alma, até o ponto em que faz desta o âmbito onde emerge outro conhecimento de si mesmo mais amplo e mais profundo, em que se determina como idêntico ao conhecimento que Deus tem de si justamente em seu intelecto infinito.

Este conhecimento, que surge como conhecimento do terceiro gênero, mostra ao sujeito sua forma como a idéia em que Deus se conhece e se constitui a si mesmo, e é, à diferença da razão que surge como conhecimento do segundo gênero, e a experiência sensível, do primeiro, conhecimento intuitivo ou visão intuitiva em que o sujeito, ao ser em Deus, descobre-se eterno e infinito ${ }^{14}$ :

A nossa alma, na medida em que se concebe a si mesma e ao seu corpo do ponto de vista da eternidade, tem necessariamente conhecimento de Deus e sabe que existe em Deus e é concebida por Deus.

A eternidade é a própria essência de Deus, enquanto esta envolve a existência necessária. Portanto, conceber as coisas do ponto de vista da eternidade é conceber as coisas enquanto são concebidas pela essência de Deus como entes reais, ou seja, enquanto, pela essência de Deus, envolvem a existência; e, por conseguinte, a nossa alma, na medida em que se concebe a si mesma e ao seu corpo do ponto de vista da eternidade, tem necessariamente conhecimento de Deus e sabe, etc. (Espinosa 7, E, V, prop. XXX e dem.)

O sujeito, na medida em que se vincula imediatamente a seu próprio princípio, o intelecto infinito de Deus, toma consciência de si como existindo nele, pois se reconhece como idêntico à idéia pela qual Deus se conhece e determina como causa de si mesmo. O conhecimento intuitivo ou do terceiro gênero — conhecimento sub specie ceternitatis - é para Espinosa um conhecimento supra-racional em que a afirmação do conatus humano desdobra-se no intelecto infinito de Deus enquanto síntese de Deus mesmo como poder absoluto de pensar e poder absoluto de existir. ${ }^{15}$

Neste contexto, Espinosa retoma a noção neoplatônica do amor Dei intellectualis, 
no qual o sujeito encontra a plena satisfação de sua essência na medida em que participa plenamente do amor e conhecimento que Deus tem de si, enquanto se conhece como causa de si mesmo ${ }^{16}$ :

Deus ama-se a si mesmo com um amor intelectual infinito.

Deus é absolutamente infinito, isto é, a natureza de Deus goza de uma perfeição infinita, e isto acompanhado da idéia de si mesmo, isto é, da idéia da sua causa; e foi isto que nós dissemos que era o amor intelectual, (Espinosa 7, E, V, prop. XXXV e dem.)

O amor intelectual da alma relativamente a Deus é o mesmo amor de Deus, com que ele se ama a si mesmo, não enquanto é infinito, mas enquanto pode explicar-se pela essência da alma humana, considerada do ponto de vista da eternidade; isto é, o amor intelectual da alma relativamente a Deus é parte do amor infinito com que Deus se ama a si mesmo. (Espinosa 7, E, V, prop. XXXVI)

Graças ao amor intelectual a Deus, o homem participa plenamente do amor que Deus tem a si, pois sua alma exprime a forma mesma de Deus, que se satisfaz em seu intelecto infinito, que surge precisamente tanto como a causa imanente do homem, quanto como a idéia em que Deus se reconhece e se ama enquanto causa de si mesmo. O amor intelectual de Deus é tanto amor do homem a Deus quanto amor de Deus a si mesmo que engloba o homem. ${ }^{17}$

Espinosa não aceita o dogma da encarnação nem as noções de queda e redenção, o que não impede que veja em Cristo, na Vida ou no Verbo divino, a idéia na qual Deus se conhece e constitui a si mesmo. Cristo ou a vida surge tanto como a forma de Deus, quanto como princípio imanente da natureza humana, que nele encontra sua afirmação $\operatorname{precisa}^{18}$ :

E para exprimir mais claramente minha opinião [...] digo finalmente que para salvar-se não é absolutamente necessário conhecer Cristo segundo a carne; de forma muito distinta, entretanto, há-se de opinar sobre aquele filho eterno de Deus, ou seja, a sabedoria eterna de
Deus, que se manifestou em todas as coisas e, sobretudo, na alma humana e, mais que nenhuma outra coisa, em Jesus Cristo. Mas sem essa sabedoria ninguém pode chegar ao estado de beatitude, já que só ela ensina o que é o verdadeiro e o falso, o bom e o mau. E como, conforme foi dito, essa sabedoria manifestou-se, acima de tudo, em Jesus cristo, por isso seus discípulos a pregaram tal como foi revelada por ele e mostraram que poderiam glorificar-se mais que ninguém do espírito de Cristo. (Espinosa 6, Ep, Carta LXXIII)

Espinosa vê a completa afirmação da essência do sujeito na criação de idéias adequadas, afecções ativas e a assimilação de tudo que concorda com sua natureza. Esta afirmação tem como resultado a criação de unidades de ser mais amplas e culmina no vínculo do homem com Deus, com o próprio intelecto infinito de Deus, Cristo, no qual Deus mesmo se autogera, se conhece e se ama a si mesmo.

Neste sentido, como adiantamos, Espinosa vê no amor ao outro, na ágape, o princípio da construção de uma ordem intersubjetiva que, dentro ou fora do Estado, ao favorecer uma ordem social justa ou em oposição a um tirano, constitui-se como a construção do indivíduo superior, como a afirmação de Deus enquanto Cristo ou o intelecto infinito pelo qual Deus mesmo se reconhece como causa de si. $\mathrm{O}$ amor ao outro ou caridade é o amor que Deus tem a si mesmo, enquanto se atualiza no homem e que também é o vínculo do homem com Deus. O amor ao outro é a via para realizar a própria essência do sujeito em Deus ou para atualizar a ordem divina no humano.

O filósofo, referindo-se ao caráter do ensino dos profetas, assinala que acertam ao afirmar que o amor do homem pelo homem, a caridade ou ágape, é fundamental para conhecer Deus:

É altura de passarmos então ao segundo ponto, isto é, de mostrar que Deus não exige aos homens, através dos profetas, que conheçam dele outra coisa que não seja a sua divina justiça e caridade, quer dizer, aqueles atributos que os homens podem imitar mediante uma certa regra de vida. É o que Jeremias ensina em termos absolutamente claros. Diz ele, falando do rei Josias, no Cap. XXII, 15, 16: "na verdade, o teu pai comeu e bebeu; foi reto e fez justiça, 
e por isso prosperou; atendeu aos direitos do pobre e do indigente, e por isso prosperou; porque isso é conhecer-me, disse Jeová". Não menos claro é o que vem no cap. IX, 23: "mas cada um vangloriese apenas de conhecer e de saber que eu, Jeová, pratico a caridade, a retidão e a justiça sobre a terra, porque é isso que me agrada". (Espinosa 12, TTP, XIII, 170-171)

Segundo Espinosa, a satisfação da essência humana não se traduz numa via negativa que tenha como meta o desprendimento do mundo da multiplicidade para possibilitar ao homem seu vínculo com o Uno. A participação num princípio transcendente e a conseqüente negação da Natureza Naturada não é para Espinosa o fundamento da completa atualização da forma humana. Pelo contrário, é na realização do reino de Deus na Terra, entendida como a construção de uma ordem intersubjetiva justa, baseada no amor — ordem oposta a toda concepção metafísica e social fundada nas noções de transcendência e hierarquia - que o sujeito há de alcançar a vivencia do indivíduo superior e a completa promoção de sua essência. A justiça como expressão da caridade é a manifestação efetiva da construção de um indivíduo superior em que o sujeito tornará certa a atualização de seu princípio imanente, a vida ou o intelecto infinito de Deus, alcançando assim a exata afirmação de sua forma humana.

$$
* * *
$$

Espinosa, graças à noção de imanência, situa-se inteiramente tanto no moderno problema do conhecimento como nas modernas reflexões sobre a noção de lei natural que fazem estourar as concepções metafísicas da Idade Média e seu correlato na determinação de um cosmos hierarquizado: a natureza, enquanto ordem necessária sujeita a leis, tem que ser conhecida por uma função racional que garanta a produção de certeza graças aos critérios cartesianos de claridade e distinção, e não pelo exercício da lógica de gêneros e espécies que supõe uma gradação dos seres e que se determina segundo a distância ou a proximidade deles com relação a um primeiro princípio. A razão, ao ser expressão do atributo pensante que é seu princípio, possui a faculdade de criar os conceitos que, por sua adequação e sua coerência interna, apresentam a verdade como critério intrínseco. Esta não tem que gerar uma adequação entre seus conceitos e certas essências transcendentes para assegurar a forma mesma da verdade. Neste sentido ainda, a própria noção de imanência é a bússola que permite a nosso autor orientar suas concepções éticas com relação à estrutura do valor moral: o valor moral é expressão de um homem que ao praticar a virtude faz de seus juízos de valor e de suas afecções ativas a afirmação de seu conatus. A virtude não é concebida como a sujeição do homem a uma lei ou um valor transcendente que lhe sejam impostos desde sua exterioridade. Espinosa rechaça toda moral heterônoma que não reconheça o poder criativo do sujeito, poder criativo que surge como horizonte constitutivo das idéias adequadas e as afecções ativas em que este se constitui como tal. Espinosa, graças à noção de imanência, devolve ao sujeito uma autonomia epistemológica e moral que a metafísica da transcendência, se não tinha terminado por anular, limitara significativamente. A noção de imanência é a via pela qual Espinosa recupera para o sujeito uma autonomia epistemológica e moral que contrasta nitidamente com as concepções que a tal respeito a filosofia aristotélico-tomista da baixa Idade Média apresenta. Neste mesmo horizonte de reflexões faz-se evidente que para nosso autor a sociedade não tem que se constituir numa estrutura hierárquica que reproduza a pretensa estrutura também hierárquica do real, mas tem que impulsionar a construção de um indivíduo superior — fundado na caridade e na justiça—, que é cabal expressão do exercício da autonomia humana.

Ora, neste contexto, novamente, cabe perguntar: por que Espinosa emparelha suas concepções de corte ontológico, epistemológico e ético, às próprias concepções de conhecimento intuitivo ou visio Dei Intellectualis e intelecto infinito de Deus como Cristo? Por que Espinosa sublinha com tanta força a forma do conhecimento do segundo gênero, quando a cabal afirmação da forma humana está dada pelo conhecimento do terceiro gênero? Por que nosso autor outorga tanta importância à autonomia moral, quando é em Deus que o sujeito encontrará seu máximo bem? Em suma, por que Espinosa põe o relevo na autonomia humana e em seu exercício na construção do indivíduo superior, se em última instância sua doutrina inscreve-se no contexto de um posicionamento religioso?

Como adiantamos, em nosso julgamento é exatamente a recuperação do sentido fundamental da posição religiosa judaico-cristã, a partir da noção de imanência, o princípio que permite tornar inteligível a convivência dos elementos propriamente modernos e 
neoplatônico-cristãos na filosofia de nosso autor. É graças à afirmação da autonomia humana que o homem vincula-se ao divino, dando lugar à realização da ordem divina na ordem humana. Como Deus, o homem ganha, ao fazer nascer Deus no homem. Espinosa estabelece uma relação dialética em que a autonomia do homem e seu vínculo com o divino se promovem e enriquecem reciprocamente, pois o homem vincula-se com Deus a partir unicamente da propagação da caridade e da justiça, e a conseguinte construção do reino de Deus na Terra: para nosso autor a imanência e a autonomia humana encontram sua expressão mais elevada no amor a Deus, e o amor a Deus só se afirma a partir de uma imanência e uma autonomia que se traduzem na própria afirmação - epistemológica, ética e política - do homem.

Espinosa desmonta a arquitetura interna da filosofia aristotélico-tomista, precisamente para restituir à posição religiosa judaico-cristã seu sentido mais arcaico como uma mútua promoção do homem e Deus que entranha a exigência de um sujeito autônomo. Espinosa filosofa no contexto de uma modernidade que conhece sua emergência e que justamente graças à decidida afirmação da autonomia humana, pode recolocar-se o problema religioso: tradição judaico-cristã e modernidade fecundam-se reciprocamente no pensamento de Espinosa, pois toda vez que a intuição faz-se vínculo do homem com Deus, faz-se também o princípio de uma autonomia do sujeito que é fundamental no mundo moderno.

Espinosa não precisa renegar ao homem sua condição humana: quiçá a singularidade e a perene vigência de seu pensamento radiquem-se nisso. Sendo porta-voz de uma Modernidade que busca ganhar sua forma, ele afirma uma imanência pela qual o homem constrói o seu próprio caráter. Nisso se pode resumir o que é divino no homem. Como dizíamos noutro trabalho (Ezcurdia 13), nisso radica a preocupação espinosana de elaborar uma ética, sendo fiel assim à velha tarefa do filosofar.

\section{REFERENCIAS BIBLIOGRÁFICAS}

1. BERGSON, H. La pensée et le mouvant, "L'intuition philosophique". In: Euvres. Paris: PUF, 1991.

2. BOVE, L. La stratégie du conatus. Paris: Vrin, 1996.

3. CASSIRER, E. "Spinoza”. In: El problema del conocimiento. México: FCE, 1965.

4. COHEN, D. El suicidio: deseo imposible o la paradoja de la muerte voluntaria en Baruj Spinoza. Buenos Aires: Ediciones del Signo, 2003.

5. DELEUZE, G. Spinoza y el problema de la expresión. Barcelona: Mario Muchnik, 1975.

6. ESPINOSA. Correspondencia. Madri: Alianza, 1988.

7.___Ética. México: FCE, 1958.

8. _. Pensées métaphysiques. Trad. Charles Appuhn. Paris: Garnier-Flammarion, 1965.

9. _. Tratado breve. Madri: Alianza, 1988.

10. _. Tratado de la reforma del entendimiento. Madri: Alianza, 1998

11. . Tratado político. Madri: Técnos, 1985.

12. Tratado teológico-político. Madri: Alianza, 1990.

13. EZCURDIA, J. Spinoza ¿místico o ateo? Inmanencia y amor en la naciente Edad Moderna. Guanajuato: Instituto de Investigaciones en Educación, Universidad de Guanajuato, 2005.

14. GEBHARDT, C. Spinoza. Buenos Aires: Ed. Losada, 1940.

15. KAMINSKY, G. Spinoza: la política de las pasiones. Barcelona: Gedisa, 1990.

16. MALINOWSKY-CHARLES, S. "Habitude, connaissance et vertu chez Spinoza". Dialogue, XLIII, 2004.

17. NEGRI, A. La anomalía salvaje. Ensayo sobre poder y potencia en B. Spinoza. Barcelona: Antropos-UAM Iztapalapa, 1993.

18. PREPOSIET, J. "L'élément irrationnel dans le spinozisme". Philosophique, 1998.

19. ROUSSET, B. "L'être du fini dans l'infini dans la philosophie de Spinoza". Revue de philosophie, 18, 1986

20. TOSEL, A. "De la ratio à la scientia intuitiva ou la transition éthique infinie selon Spinoza". Philosophique, 1998

21. ZAC, S. "Vie, Conatus, Vertú. Rapport de ces notions dans la philosophie de Spinoza". Archives de la philosophie, 1963.

22. . L'idée de vie dans la philosophie de Spinoza. Paris: PUF, 1963. 


\section{Immanency and love in Spinoza's philosophy}

Abstract: The following text presents a non-common interpretation of Spinoza's philosophy, as it recovers not only the modern elements in which this philosophy lays, but the peculiar appropriation that Spinoza does of the concepts linked to the Neoplatonic-Christian tradition, such as life, amor Dei intellectualis, charity or the figure of Christ itself that appears in Spinoza's correspondence. In this sense, the explicitation of the content and the relation between the concepts of immanency and love, appears as a helping point to remark that Spinoza's doctrine is articulated on making a renovation of some of the most archaic Judaeo-Christian religious approaches - the conception of loving the fellow human being as the divinization of the man in God and, at the same time, as the realization of God in the man, fundamentally -, that satisfy the guidelines of a Modernity that finds in the affirmation of the autonomy of the subject, one of the bases that guarantees its emergence.

Keywords: life, charity, Christ, immanency, love

\section{NOTAS:}

1. As citações de Espinosa apresentam-se com a notação de C. Gebhardt: obra, livro e página, por exemplo: (TTP, III, 45-46); à exceção da Ética, que apresenta a notação própria deste texto: livro, proposição, demonstração, corolário: (Ética, I, prop. XVI e dem.). Para assinalar as obras da Espinosa citadas, apresentam-se as abreviaturas utilizadas por Atilano Domínguez em suas edições da Alianza Editorial: $\mathrm{CM}=$ Cogitata Metaphysica (Pensamentos metafisicos); E=Ethica (Ética) Ep=Epistolce (Correspondência); $\mathrm{IE}=T$. de Intellectus Emendatione (Tratado da reforma do intelecto) ; KV=Korte Verhandeling (Tratado breve); $\mathrm{PPC}=$ Pr. Philosophice Cartesiance (Principios de filosofia cartesiana); $\mathrm{TTP}=$ Tractatus teologico-politicus (Tratado teológico-político). [Sempre que possível, procedendo a certos ajustes, utilizarammos as traduções de Espinosa disponíveis em português: a do Teológico-político por Diogo Pieres Aurélio, Martins Fontes, e as da coleção Os Pensadores; N. do T.].

2. Cf. Deleuze 5, p. 171, onde o autor assinala os nexos históricos da expressão e da imanência, em função da determinação de sua forma e relação no pensamento da Espinosa. A respeito, ele assinala: “A idéia de expressão dá conta da verdadeira atividade do partícipe e da possibilidade da participação. É na idéia de expressão que o novo princípio da imanência afirma-se. A expressão aparece como a unidade do múltiplo [...] O próprio Deus se exprime no mundo; o mundo é a expressão, a explicação de um Deus [...] que é o ser ou do Uno que é"

Deleuze situa a noção de explicatio no pensamento de Espinosa na linha de um conceito de emanação neoplatônica que evoluiu rumo à imanência. Deus como causa aparece não parcial, mas totalmente em seu efeito. $O$ efeito não é, assim, uma degradação da causa, mas sim a expressão em que se constitui como tal. Espinosa, ao adotar a noção de imanência, ao mesmo tempo em que adere à tradição neoplatônica, renova-a e outorgalhe uma nova orientação. Cf. Deleuze 5, p. 15: "Quanto à emanação, é certo que dela, tal como da participação, achar-se-ão traços em Espinosa. Precisamente a teoria da expressão e da explicação, tanto no Renascimento como na Idade Média, formou-se em autores fortemente inspirados pelo neoplatonismo. Resta que [Espinosa] teve por meta e por efeito transformar profundamente esse neoplatonismo, abrir-lhe vias totalmente novas, afastadas da emanação, inclusive se ambos os temas coexistiam [...] É a idéia de expressão que pode mostrar como o neoplatonismo evoluiu até mudar de natureza, em particular como a causa emanativa tendeu mais e mais a converter-se em causa imanente".

3. Cf. Deleuze 5, p. 100: "Há uma ordem no que Deus produz necessariamente. Esta ordem é a da expressão dos atributos. Primeiro, cada atributo se exprime em sua natureza absoluta: um modo infinito imediato é, pois, a primeira expressão do atributo [...] $\mathrm{O}$ atributo se exprime de uma maneira certa e determinada ou, antes, de uma infinidade de maneiras que constituem os modos existentes finitos. Este último nível permaneceria inexplicável se os modos infinitos, no gênero de cada atributo, não contivessem leis ou princípios de leis segundo as quais os modos finitos correspondentes são eles mesmos determinados e ordenados".

4. Cf. Deleuze 5, p. 112, relativamente à determinação da essência divina como poder de existir na filosofia de Espinosa: "A expressão se apresenta aqui como a relação da forma e do absoluto: cada forma exprime, explica ou desenvolve o absoluto, mas o absoluto contém ou 'complica' uma infinidade de formas. A essência absoluta de Deus é potência absolutamente infinita de existir e atuar; mas, precisamente, se afirmamos esta primeira potência como idêntica à essência de Deus é sob a condição de uma infinidade de atributos formal ou realmente distintos. Potência de existir e atuar é, pois, a essência formal-absoluta [de Deus].

5. Cf. Rousset 19, p. 232: "Em resumo, segundo a ontologia da primeira parte da Ética, o ser infinito e único, na infinidade de suas ordens infinitas de existência [atributos], é, segundo as modalidades infinitas das determinações de sua existência [leis], nas modalidades finitas de seu ser que são as concreções [modos], extrinsecamente determinadas, mas capazes de receber determinações intrínsecas das modalidades infinitas de determinação. Nesse edifício impressionante não há mediação a encontrar, pois não há mediação a buscar; não há mediação porque as relações dos termos não são relações entre os seres, mas relações do ser no ser, suas ordens de existência e suas modalidades de existência, suas leis infinitas e sua concreção no infinito; é precisamente isso que significa a determinação de uma substância una e única, ao mesmo tempo que infinita, a redução 
das substâncias cartesianas [extensão e pensamento] ao ser atributivo, a redução dos indivíduos substanciais ao ser modal, e a promoção das leis da natureza à categoria de modos eternos; é por isso também que o ser do finito no infinito, em seu ser real, positivo e ativo, não é um 'participar', mas um 'ser parte de'."

6. Cf. Zac 22, p. 126: “A consciência é do mundo. Não há dois setores, a consciência e a natureza. A consciência que Deus tem de si mesmo, Espinosa o repete em múltiplas ocasiões, pertence à Natureza Naturada; a Natureza desvela-se a si mesma tal como ela é".

7. A respeito, cf. Zac 22, p. 38: “Ao ligar a idéia de causalidade imanente de Deus à idéia de Vida, o pensamento de [Espinosa] integra-se na tradição judia. Deus é a Vida e a fonte de Vida. A vida de Deus dá conta da existência e da essência das coisas".

Neste contexto, igualmente, cf. Preposiet 18, p. 58: "No universo espinosano, todos os seres - e não somente os homens — são dotados de alma (omnia animata), ainda que em diferentes graus. E mais, Espinosa reteve do judaísmo, que foi sua formação primeira, não o esqueçamos, a idéia de um Deus não somente vivente, mas que é a própria vida".

8. Cf. Cassirer 3, p. 23: "Neste tipo de conhecimento, o intelecto já não é algo condicionado, mas o elemento condicionante. A 'idéia' adquire agora a significação e a importância que o sistema maduro de Espinosa a atribui. A idéia não deve ser depreciada como se fosse a imagem muda pintada num quadro, mas sim nasce na afirmação ou na negação. É, pois, antes um conceito que uma imagem, deve ser chamada de 'conceptus' e não 'perceptio', já que só assim exprimimos que não é algo que seja dado de fora, mas que deve sua origem pura e exclusivamente ao espírito."

9. Cabe aqui assinalar que Espinosa, na Reforma, não distingue expressamente o erro da ficção e da dúvida, mas assinala tão-somente sua origem comum: a passividade do intelecto.

10. Kaminsky sublinha a importância do desejo no sistema filosófico de Espinosa como estrutura a partir da qual o sujeito, enquanto perseverar no ser, determina-se como tal. Cf. Kaminsky 15, p. 43: "As modificações que [o homem] pode experimentar não são todas necessariamente nocivas; pelo contrário, sua potência de agir pode ser aumentada e esse é o desejo essencial do humano. O perseverar pode ser bem definido como paixão de ser". 11. Cf. Deleuze 5, p. 238: "O que é o mal? Não há outros males que a diminuição de nossa potência atual e a decomposição de uma relação. Inclusive a diminuição dessa potência de atuar não é um mal senão porque ameaça e reduz a relação que nos compõe. Reterse-á, pois, do mal, a seguinte definição: é a destruição, a decomposição da relação que caracteriza um modo. Em conseqüência, o mal não pode supor-se senão do ponto de vista particular de um modo existente: não há bem nem mal na Natureza em geral, porém há o bom e o mau, o útil e o prejudicial para cada modo existente. O mal é o mau do ponto de vista desse ou daquele modo. Sendo nós mesmos homens, julgamos o mal de nosso ponto de vista, e Espinosa recorda com freqüência que fala do bom e do mau considerando exclusivamente a utilidade do homem".

12. Aqui é pertinente assinalar que Espinosa faz da psicologia e da ética o domínio de aplicação do método. As afecções são, para o autor, idéias que, ao serem conhecidas clara e distintamente, apresentam uma adequação que possibilita a exata construção ou realização da essência do sujeito, segundo as leis em que articula sua própria natureza. 13. Cf. Zac 21, p. 426, em que se assinala a forma da virtude como manifestação da própria vida enquanto princípio imanente do sujeito, que não atende mais que a si mesma para realizar-se como tal: "Enfim, embora o homem dotado de virtude procure o útil para si mesmo, a própria virtude é incondicional: ninguém, com efeito, esforça-se por conservar seu ser por causa de outra coisa. Ao procurar aquilo que é útil à vida, vida do corpo e vida da alma, a vida busca-se a si mesma. Espinosa está de acordo com o rei Salomão que a virtude é sua própria recompensa, o que ele pensa é que a virtude é uma conquista da vida e que o signo dessa conquista é o gozo que a define como o passo de uma perfeição menor a outra maior".

Cf. Bove 2, p. 25, em que o autor sublinha o caráter essencialmente ativo do conatus, ao assinalar o suicídio como resultado da imposição sobre este de uma série de imagens mais potentes que ele mesmo e que conduzem a sua negação. O sujeito não pode suicidar-se senão perdendo contato com sua própria natureza ativa: "No caso da alma de um corpo esgotado, arrebentado por forças exteriores, impotente para realizar novas contrações, ela contempla no processo de dissolução do corpo mesmo a imagem de sua desesperança, quer dizer, sua tristeza definitiva. Entretanto é um postulado fundamental do espinosismo afirmar que não existe nada que busque, por sua própria natureza, sua própria destruição e que assim o homem jamais pode desejar morrer ou estar triste e que todo seu esforço essencial é suportar a depressão e a tristeza, ainda que este esforço seja freqüentemente vencido. Há por que conceber o suicídio como uma derrocada do desejo e não como uma das vias do desejo enquanto tal: a morte jamais é desejada por si mesma".

14. Cf. Preposiet 18, p. 63: "Porém, a sabedoria ainda não é a salvação. A comunidade dos seres racionais não é o terreno da felicidade suprema. A vida segundo a razão é uma condição necessária, mas não suficiente para alcançar a beatitude. É somente do conhecimento do terceiro gênero que nascerá a maior satisfação do espírito. E Espinosa recorda que, quanto mais se é capaz deste gênero de conhecimento, mais se é consciente de si mesmo e de Deus. Com efeito, a idéia de si mesmo, acompanhada da idéia de Deus como causa, tal como a intuição a mostra, conduz Espinosa à consciência de sua eternidade em Deus, fazendo nascer o que ele chama o amor intelectual a Deus".

15. Cf. Zac 22, p. 191: "Quando os homens seguem o itinerário que Espinosa indica, eles se salvam, porque vivem no e pelo intelecto infinito de Deus. Produz-se então uma união de consciências, um acordo de intelectos no intelecto infinito de Deus, que faz pensar 
nisso que os teólogos cristãos chamam a comunhão dos santos".

16. Cf. Tosel 20, p. 202: "O amor intellectualis Dei se dirige a Deus na medida em que nasce do conhecimento das coisas (e do próprio corpo), sub specie ceternitatis, ou seja, das coisas consideradas em seu elo de identidade necessária com Deus. Tal é a beatitude, a alegria que nasce da e que se identifica com a compreensão das individualidades que não cessam de produzir-se e de suas leis de produção, compreensão que inclui a singularidade de cada espírito-idéia de um corpo determinado".

17. Cf. Gebhardt 14, p. 31, em relação aos ascendentes doutrinais do Deus espinosano: "Leão Hebreu, do platonismo renovado pelo Renascimento, extrai uma concepção do mundo apoiada no amor como força cósmica. Espinosa orientou sua teoria dos valores na de Leão Hebreu; ele desenvolve a combinação do conceito de uma razão universal com a teoria das idéias do Platão, sobre a qual se funda a teoria do conhecimento de Leão Hebreu, em sua teoria da razão infinita e das essências [...] Finalmente, Espinosa toma, em conceito e fórmula, a teoria de Leão Hebreu da fusão do amor de Deus e o conhecimento de Deus no amor intelectual do espírito a Deus. Se Maimônides oferece a Espinosa o primeiro esquema da teoria escolástica do ser, Leão Hebreu lhe proporciona o mito de um mundo dinâmico adequado ao novo sentido de vida de sua época".

18. Cf. Zac 22, p. 191: "O intelecto infinito de Deus é como Cristo, 'Filho eterno de Deus', porque não se lhe poderia separar. Ele é a sabedoria universal, porque é o conhecimento adequado de Deus mesmo e de tudo o que dele se deriva e, ao mesmo tempo, fonte de vida e comunhão".

Igualmente, cf. Deleuze 5, p. 295, em que se distingue o conhecimento do segundo gênero, capaz de dar conta das noções comuns, do conhecimento do terceiro gênero, capaz de dar conta da figura de Cristo: "Esta condição de nosso conhecimento não é uma condição para todo conhecimento: o verdadeiro Cristo não passa pelas noções comuns. Adapta, conforma às noções comuns o ensino que ele nos dá; mas seu próprio conhecimento é imediatamente do terceiro gênero; a existência de Deus lhe é pois conhecida por si mesma, como todas as essências e a ordem das essências. É por isso que Espinosa diz: diferentemente de Cristo, nós não conhecemos a existência de Deus por si mesma".
A NOÇÃO DE CONTEMPLAÇÃO NO LIVRO II

DA ÉTICA DE ESPINOSA

\section{Luís César Oliva*}

Resumo: O trabalho investiga o conceito de contemplação no livro II da Ética de Espinosa, levantando os usos do termo, bem como seu sentido preciso, nos contextos de cada um dos gêneros de conhecimento propostos pelo filósofo. A análise destes casos indica que Espinosa utiliza o termo para indicar o conhecimento de singulares, seja no terreno da inadequação (primeiro gênero) ou da adequação (terceiro gênero). As aparições do termo nas proposições sobre o segundo gênero (conhecimento de propriedades gerais) não comprometem a hipótese, pois não visam ao objeto propriamente dito deste gênero de conhecimento, mas a uma etapa prévia deste.

Palavras-chave: Espinosa, contemplação, imaginação, razão.

Este trabalho é o início de uma investigação a respeito do termo contemplação na Ética de Espinosa. Não havendo, até onde eu sei, um trabalho prévio sobre isso, a investigação se justificaria naturalmente, desde que, é claro, houvesse indícios de que o referido termo tem um papel relevante no percurso argumentativo da obra. Os trechos abaixo selecionados acompanham as ocorrências freqüentes do termo no livro II da Ética e meus comentários buscam mostrar que se trata de um uso específico e não de um mero recurso a um sinônimo de "ver" ou "considerar", ao mesmo tempo em que tentam explicitar qual é este uso. Quanto à relevância de tal termo para a filosofia de Espinosa (a qual só poderá ser plenamente estabelecida após estudos similares das partes III e V), podemos encontrar indício suficiente para ela na demonstração da proposição 36 da parte $\mathrm{V}$ :
O Amor intelectual da Mente a Deus é o próprio Amor de Deus pelo qual Deus ama a si próprio, não enquanto é infinito, mas enquanto pode ser explicado pela essência da Mente humana considerada sob o aspecto da eternidade, isto é, o Amor intelectual da Mente a Deus é parte do amor infinito pelo qual Deus ama a si mesmo. 